\title{
APP-063 高コレステロール血症、総腸骨動脈内膜損傷ラットにおける膀腅機能の検討
}

\author{
福島県立医科大学医学部泌尿器科 \\ 野宮 正範, 高橋 則雄, 吉田 純也 , 矢崎 順二 , 相川 健, 山口 脩
}

【目的】最近、メタボリック症候群という概念が提唱されており、高脂血症に伴う動脈硬化によって引き起こされる慢性的な虚血 は、様々な臓器で機能障害を呈することが指摘されている。今回我々は、総腸骨動脈内膜損傷（AI）と高コレステロール食での飼 育が、ラットの膀胱形態とその機能にどのような影響を与えるのかを検討した。【対象】 16 週 S-D 雄ラット 17 匹 (体重 $450 \mathrm{~g}$ 前後) を、コントロール群 5 例、sham 群 5 例、AI 群 7 例に分けた。【方法】 AI 群は、両側鼠径部に皮切を置き、大腿動脈を同定後、2.5Fr 閉塞術用血管内カテーテルを総腸骨動脈まで挿入し、拡張させたバルーンを数回引き抜き内膜損傷を作成、その後 8 週間、高コレ ステロール食を与えた。sham 群は、両鼠径部に皮切のみ置き、高コレステロール食 8 週間、コントロール群は、普通食を 8 週間 与えた。この 3 群に扔ける、血糖、トリグリセリド、コレステロール值と代謝ゲージによる 3 日間の Frequency Volume Chart (FVC) と無麻酔下膀胱内圧測定 (CMG) データの比較検討㧍よび摘出した総腸骨動脈と膀胱の組織学的検討を行った。【結果】各群に おける体重、膀胱摘出重量、血糖、トリグリセリド值に有意差を認めなかった。総コレステロール值は、コントロール群 $70.2 \pm$ $15.0 \mathrm{mg} / \mathrm{dl}$ に比し、sham 群と AI 群で各々 $159.8 \pm 53.0 、 154.0 \pm 61.5 \mathrm{mg} / \mathrm{dl}$ と有意に高値を示した。FVCに抢ける平均一回排尿量は、 コントロール群 $1.31 \pm 0.24 \mathrm{ml}$ 、sham 群 $1.15 \pm 0.14 \mathrm{ml} 、 \mathrm{AI}$ 群 $0.87 \pm 0.22 \mathrm{ml}$ と $\mathrm{AI}$ 群で有意に減少していた。CMGでの平均一回排 尿量も FVC と同梯に他群に比べ、AI群で有意に隇少していた。いずれの群でも残尿を認めなかった。なお、FVCと CMGによる 平均一回排尿量の関倸は、強い正の相関を示した。組織学的検討では、AI 群の総腸骨動脈に、内膜の肥厚を認めたが、sham 群、 コントロール群では、変化を認めなかった。膀胱に関して、AI 群は、間質への線維芽細胞の増生と微小血管の壁肥厚に伴う内腔の 狭小化を認めた。【考案】高コレステロール血症のみでは、膀胱機能に影響を与えなかったが、そこに、総腸骨動脈内膜損傷に伴う 血管壁の肥厚が加わった場合、膀胱に器質的機能的変化が生し、膀胱容量の減少が認められた。このことから、臨床上の特発性過 活動膀胱の発生メカニズムに、動脈硬化による慢性的な膀胱血流の低下の関与が示唆された。本ラット病態モデルの最大の特徴は、 膀胱や尿道への操作を必要とせず、臨床現場に即し、FVCにて、過活動膀胱ラットを鑑別できることである。

\section{APP-064ＩPSS の各症状に特異的な QOL を評価する VAS 質問票による治療効果判定の検討}

\author{
京都府立医科大学医学部泌尿器科 \\ 牛嶋 壮, 浮村 理, 藤原 敦子, 問山 大輔, 沖原 宏治, 高羽 夏樹, 水谷 陽一, 河内 明宏, 三木 恒治
}

【目的】現在、下部尿路症状（LUTS）の重症度は国際前立腺症状スコア（IPSS）を用いて評価されているが、IPSSで 最も高いスコアの症状は必ずしも患者が治療を望む症状と一致しているわけではない。例えば他の症状のスコアがょり 高くとも、1もしくは 2 回の夜間排尿がその患者のQuality of Life（QOL）に大きく影響していることがある。我々は Visual Analogue Scale（VAS）法を用いた国際前立腺症状スコア（IPSS）の各症状に特異的な満足度を問う質問票を作 成し、IPSS と併用して患者の主訴の同定に有用であると報告してきた。そこで今回はVAS 法と IPSS の治療前後での変 化について検討した。【方法】IPSSの各項目に特異的な满足度を表現するため、「とても满足」から「とてもいやだ」ま での $10 \mathrm{~cm}$ の直線上に×印で回答するVAS 質問票を作成した。LUTSに対して $a$ 遮断薬もしくは抗コリン薬を内服中の 患者 94 名に、治療前後で少なくとも 2 週間の間隔をあけて IPSS と VAS 質問票を回答させ、その変化につき検討を行った。 【成績】 VAS 及び IPSS 各項目の変化と IPSS-QOL，との相関については、それぞれ残尿感が 0.54 と 0.49、頻尿が 0.49 と 0.67 、 尿線途絶が 0.52 と 0.47 、尿意切迫感が 0.45 と 0.51 、尿勢低下が 0.50 と 0.57 、腹圧排尿が 0.25 と 0.29 、夜間頻尿が 0.36 と 0.57 であり、 7 項目中 5 項目でVAS 質問票が高値を示した。多変量解析の結果、IPSS も含めた計 14 項目の変化におけ る IPSS-QOL の変化の有力な予測因子は IPSS の残尿感（F 值：6.0）、VAS の尿勢減弱（F 值：4.8）、VAS の夜間頻尿（F 值:4.0）であった。患者の主訴項目について、治療前後での VAS 質問票の変化と IPSS-QOLの変化との相関（r=0.79）は、 IPSSに打ける変化との相関（r=0.61）よりも高かった。【結論】IPSSの合計点数の重症度が総合的な QOLを示す IPSSQOL に大きく影響していることはよく知られているが、IPSS で最も高いスコアの症状と患者の困窮度は必ずしも一致し てない。有効な治療を行うには、患者の主訴もしくは最も困っている症状に対する治療が求められる。VAS 質問票を使 用し、各症状に関するQOL の評価することにより患者にとって最も重要な症状を同定でき、QOLを尊重した治療に貢 献できると考えられた。 